\title{
Professionals' views of material wastage on construction sites and cost overruns
}

\author{
Ameh Oko John \\ Department of Building, University \\ of Lagos, Akoka, Yaba, Lagos \\ oameh@unilag.edu.ng
}

\author{
Daniel Emmanuel Itodo \\ Department of Building, University \\ of Lagos, Akoka, Yaba, Lagos \\ itododan@yahoo.com
}

DOI 10.5592/otmcj.2013.1.11 Research paper

\section{Keywords}

Material wastage, Cost overruns, Contractual options, Construction, Nigeria
IT IS BELIEVED THAT BUILDING MATERIAL WASTAGE ON CONSTRUCTION SITES ACCOUNT FOR COST OVERRUNS AND ANY IMPROVEMENT IN BUILDING MATERIALS MANAGEMENT ON CONSTRUCTION SITES HAS THE POTENTIAL TO ENHANCE THE CONSTRUCTION INDUSTRY'S PERFORMANCE WITH COST-SAVING BENEFITS. The purpose of this study is to identify the most wasteful building material during construction operation. It also sets out to assess the level of material wastage with various subcontracting options, the percentage contribution of material wastage to project cost overrun, identify factors contributing to material waste on building sites and to examine the relationship between subcontracting options, project cost overrun and the level of waste generated from building material. A survey research design was employed. Responses from 56 site based professionals representing 70\% of the respondents were analysed using both descriptive and inferential statistics. Results indicate that the most wasteful building material during construction operation is mortar from plastering/rendering; labour-only subcontracting options have high contribution to material wastage. Furthermore, the study revealed that the average percentage contribution of building material wastage to project cost overrun is between $21-30 \%$; Poor supervision, re-work, and poor material handling were identified as dominant factors that have high contribution to material wastage on sites. Finally, the result also shows that there is a relationship between subcontracting options, cost overrun and waste generated from building material during construction. Measures to reduce material wastage on construction sites were proposed.Improvement in building materials management on construction sites has the potential to enhance the construction industry's performance with cost-saving benefits. 


\section{INTRODUCTION}

It has been observed that the construction industry remains a major economic sector, but the pollution generated from construction activities continuously present a major challenge to environmental management (Tam, Shen and Tam, 2007). Construction waste has caused serious environmental problems in many large cities (Bagum et al. 2006; Chan et al. 2002; Teo and Loosemore, 2001). Teo, Abdelnasar and Abdul (2009) observed that extra construction materials are usually purchased due to material wastage during construction. Previous studies from various countries have confirmed that waste represent relatively larger percentage of production cost. For example, Skoyles in Tam et al. (2007) in a UK study reported an additional cost of $15 \%$ to construction projects cost overruns as a result of material wastage. A study conducted by the Hong Kong Polytechnic and the Hong Kong Construction Association (1993) put material waste contribution to cost overruns at $11 \%$. Bossink and Bounwers (1996) in a similar study of material wastage in the Netherlands concluded that material wastage account for between $20-30 \%$ of project cost overruns.

Hore, Kehoe, McMillan and Penton (1997) cited in Ajayi, Koleoso, soyingbe and Oladiran (2008) opined that in every 100 houses built; there is enough waste material to build another 10 houses. Over 70 million tonnes of waste is produced in the UK construction industry each year. This amounts to $24 \mathrm{~kg}$ per person, per week in the UK, about four times the rate of household waste production (CIRIA, 1999). It is therefore glaring that the economic losses from construction material wastage could pose a great threat to the economic growth of a nation.

There is a growing consensus within the built environment in Nigeria that building materials account for over $50 \%$ of the total cost of a building project (Akinkurolere and Franklin, 2005). It therefore follows that wastage of materials will lead to increase in total cost of building project. This assertion is supported by Teo et al. (2009) who opined that building material wastage on construction sites contributes to cost overrun. This implies that any improvement in building material wastage level on construction sites has the potential to enhance the construction industry performance with cost-saving benefits.

Numerous studies on construction material wastage have been carried out in various countries. Previous studies in Nigeria, centers on waste management practice (Akinkurolere and Franklin 2005; Dania, Kehinde and Bala, 2007 and Ajayi et al, 2008). Shen, Tam, Ho and Tam (2002) observed that in Hong Kong, construction and demolition activities generate thousand tones of solid waste every year. In another study in Hong Kong, Chu (2004) identified the contribution of the following materials waste to the total project cost: concrete $4 \%$, block work $10 \%$, waste from screeding and plastering $15 \%$, packaging $5 \%$ and that of formwork is based on the number of times it is re-used. Rogoff and William (1994) pointed out that $29 \%$ of the solid wastes in the USA are construction waste, and these waste remains at an average of $15 \%$ growth every year.

Based on these, identifying the extent of waste generated by the various building material and their implication on final project cost in the Nigerian building industry will be of immense benefits both to the environment and the construction industry of developing economies. Hence the need for the present study which aims at examining the effect of material wastage on construction sites on cost overruns.

\section{Concept of material waste}

There are different views held by researchers as to what constitute construction waste. Cheung (1993) defined construction wastes as the bye- product generated and removed from con- struction, renovation and demolition work places or sites of building and civil engineering structures. Formoso, Isatto, and Hirota (1999) defines construction waste as any inefficiency that results in the use of equipments, labour, materials, or capital in larger quantities other than those considered in the production of a building. According to Shen et al. (2002), building material wastage is defined as the difference between the value of materials delivered and accepted on site and those properly used as specified and accurately measured in the work, after deducting the cost saving of substituted materials transferred elsewhere, in which unnecessary cost and time may be incurred by material wastage. Formoso, Soibelman, De Cesare, and Isatto (2002) observed that the notion of waste is directly associated with the debris removed from site and disposed off in land fills. Formoso et al. (2002) asserts that the main reason for this relatively narrow view of waste is perhaps the fact that it is relatively easy to see and measure. Although as important as such concept is from environmental perspectives, this idea has been criticized since the beginning of industrial engineering.

Keal, (2007) further stressed that any substance or object that are discarded, intend to be discarded, or are required to be discarded is waste and such is subject to a number of regulatory requirement. Dania et al. (2007) assert that Construction and Demolition waste is a complex waste stream, made up of a wide variety of materials which are in the form of building debris, rubble, earth, concrete, Steel, timber, and mixed site clearance materials, arising from various construction activities including land excavation or formation, civil and building construction site, clearance, demolition activities, roadwork, and building renovation. According to Formoso et al. (2002) the concept of material wastage in lean production paradigm is seen as resources that do not add value to the final product. 


\section{Previous studies on material wastage}

Previous studies have confirmed that the construction industry generates high level of waste from material usage. For instance, the construction industry consumes 3 billion tonnes of raw materials annually while one quarter of the world timber is used in the construction industry (UNEP, 2007; WGBC, 2010). In reality, some of these material will eventually end up as construction and demolition waste.

In the United States, 136 million tonnes of construction and demolition waste are sent into the landfill annually which amounts to about 30\% waste from the industry (Mclaren, 2009). According to (Napier, 2012), waste in construction occurs in various construction stages ranging from foundation works to finishing and they emanate from wooden materials, concrete, gravels, aggregate, masonry, metals, plastic, plumbing and electrical fixtures, glass and material handling. A more recent study in the United State between (2009-2010) from the processing of 20,000 tonnes of construction and demolition waste identified the following percentage wastage of some building materials; wood $30 \%$, concrete $5 \%$, gravels, aggregate and fines, $20 \%$, dry wall $3 \%$, Asphalt roofing $5 \%$, ferrous and non-ferrous metals, $9 \%$, plastic $1 \%$, cardboard and paper $3 \%$ and disposal as refuse $5 \%$ (Napier, 2012). Although the study concluded that the predominant waste stream in the United States comes from wood, wood however presents a high potential for reuse in construction and in other industry such as manufacturing. The US Government in its effort to reduce the impact of building material waste on the environment has implemented the green rating criteria for all building project to further improve the environmental performance (Amatruda, 2012).

In Hong Kong, an increasingly large quantity of waste are sent into the land- fill annually with 15.4 million tonnes from construction and demolition waste, which account for $23 \%$ of total waste disposed in the landfill (Yu et al, 2012; EPD, 2010). Tam et al, (2007) conducted a research in Hong Kong aimed at assessing the wastage levels of different building material on construction sites. The specific objectives of the study were to identify the most wasteful material on Hong Kong construction site, with specific focus on concrete, block, tiles, reinforcement and formwork and to also determine how public and private projects and subcontracting options affect the levels of material wastage on sites in Hong Kong. To achieve these, 19 construction project were investigated between 2003 and 2005 and quantitative approach was used. The study identified the following percentage wastage in the following building materials with labour only subcontracting option; concrete $8.99 \%$, reinforcement $7.7 \%$, formwork, $20 \%$, block/brick $8.9 \%$, and tiles $15.58 \%$. The study concluded that the most wasteful material on Hong Kong construction site is wood formwork while labour only subcontracting option and public project generates the highest level of waste. However, the Government of Hong Kong has now implemented the Construction Waste Disposal Charging Scheme (CWDCS) to help regulate the amount of waste that can be taken to landfill (Yu et al. 2013). This initiatives will not only minimise the quantity of waste generated on site but will also help the construction participants develop a holistic approach to construction waste elimination and management. According to Yu et al. (2012) the first three implementation of CWDCS has recorded a significant reduction in construction and demolition waste (C\& D) in Hong Kong.

The Australia construction industry generates about 13,000 million tonnes of waste which amounts to about $42 \%$ of the total waste generated in Australia (ABS, 2013). Baldwin et al. (2009) argued that the best way to minimise waste is to prevent it from occurring in the first instance. In view of this, Perry and Kristy, (2007) undertook a research on the Australia construction industry which was aimed at assessing brick waste on domestic construction site with a goal to identifying possibility of minimisation of its occurrence in the future. The study was conducted on 23 medium density housing and 20 detached building project in Sidney. Quantitative and qualitative approach was used by the researchers in collecting the data. The study concluded that waste from brick is the highest waste by weight generated on domestic construction site in Australia. The study further confirmed that $75 \%$ of the waste from bricks is due to cutting and it was recommended that a change in design of bricks could reduce the amount of waste generated on site. Although waste from brick/blocks can be reused or recycled, the construction industry could also device strategy for preventing it from occurring.

In Brazil, various researchers have attempted to investigate material waste on construction site (Formoso et al. 2002; Junior, 2009; Saraiva et al. 2012). Although at the general level, Brazil has not established the quantity of construction and demolition waste that goes to landfill annually, information exist for the amount of $C \& D$ waste from major locations of the country (Angulo et al. 2009; Junior et al. 2009). Brazil construction industry consumes $75 \%$ of its natural resources, $44 \%$ of total energy in use and accounts for $40 \%$ of the total waste generated in the country (Saraiva et al. 2012). A study by Brito Filho (in Junior et al. (2009) observed that the average waste material on construction site in Brazil composed of; $33 \%$ concrete and mortar, $32 \%$ soil, $30 \%$ ceramics and $5 \%$ others. Similarly, (Angulo et al. 2003; Angulo et al. 2009) further confirmed that almost all C\&D waste in Brazil come from masonry and concrete material. 
Gihan, Ahmed, and Andel's (2010) study in Egypt focused on minimising and controlling the incidence of material waste from its source. Due to the absence of an accurate database on the rates and causes of material waste in the Egyptian Construction Industry, the authors found it essential to build their research on an in-depth study that would cover the current situation. The study revealed that the highest waste rates ( $13 \%$ in average) were related to timber frameworks. However, its impact on the environment is less negative than for other materials since it is sold at the end of the project to scrap dealers which in turn use them for minor jobs. Steel, and cement waste rates seem to be within the average allowable rates of $7 \%$ and $5 \%$ respectively. This may be due to their high cost in the bill of quantities which would have led to higher effort from contractors to control their waste. Previous results from cement waste seem to contradict national data on cement consumption which suggest that $50 \%$ of cement consumption is unaccounted for. Uncompleted design and untrained labour were among the most dominant causes of waste generation. Ignorance of specifications, resource surplus, and theft actions showed minor effect on waste generation rates for the study.

Akanni's (2007) study of 146 building projects in Nigeria identified percentage contributing of various sources to material wastage on site. These include: site storage ( $43 \%)$, transportation and delivery to site (14\%), pilfering and theft ( $14 \%$ ), wrong specification (6\%), intrasite transit ( $5 \%$ ), fixing ( $5 \%$ ), wrong use (5\%), conversion waste (3\%), negligence ( $3 \%$ ) and management ( $2 \%)$. The limitation of Akanni's(2007) study is that it is based on perception rather than objective measure of waste from the sources mentioned. In a related study conducted on 12 building sites in Botswana, Urio and Brent (2006) reported an average percentage waste of $13 \%$ for sand, $11 \%$ for stone and $11 \%$ for mortar in plas-

\begin{tabular}{l|c|c|c}
\hline Variable & Frequency & $\%$ & cumulative $\%$ \\
\hline Nature of Organization & & & \\
\hline Contractors & 36 & $64 \cdot 3$ & 64.3 \\
\hline Client/property developers & 17 & 30.4 & 94.6 \\
\hline All of the above & 3 & 5.3 & 100 \\
\hline Duration of operation & 8 & 14.3 & 14.3 \\
\hline Below 5years & 10 & 17.9 & 32.1 \\
\hline $5-10$ years & 11 & 19.6 & 51.8 \\
\hline $11-15$ years & 5 & 8.9 & 60.7 \\
\hline $16-20$ years & 22 & 39.3 & 100 \\
\hline Above 20 years & & & \\
\hline
\end{tabular}

\section{Table 1 Respondents' Organizational Details}

terwork. Others are cement (10.3\%), common bricks (7.4\%), mortar in brick work $(7.2 \%)$, face bricks (6.9\%) and concrete (5.7\%).Ayarkwa and Adinyira (n.d cited in Agyekum, Ayarkwa and Adinyira, 2012) report of a wide variation in wastage rates between $5 \%$ and $27 \%$ of total materials purchased for construction projects in Ghana.

\section{Research hypothesis}

Two hypotheses were postulated for this study. First, the study sought to know if any significant relationship exists between the types of subcontracting arrangements used and level of material wastage generated on site. Hence, hypothesis one states:

Ho: There is no significant relationship between labour only, direct labour, material \& labour and direct labour \& labour only subcontracting arrangements and the level of wastes generated from building materials during construction on sites.

The study also sought to know if there is a relationship between project cost overrun and the level of material wastage for various building materials on construction sites. For this purpose hypothesis two of the study was postulated and states thus:

Ho: There is no significant relationship between project cost overrun and the level of waste generated from various building material during construction on site.

\section{Research method}

A questionnaire was used as the principal instrument for eliciting responses on the levels of material wastage on construction site from the target respondents. The survey instrument consists of two sections. Section (A) sought to know the profile of the respondents and that of their organization. Information on section (A) are meant to moderate the main part (section $B$ ). In section $B$, the respondents were required to identify the frequency of use of four subcontracting arrangements identified using five point Likert scale ranging from 1- 5 , (where $1=$ not at all, $2=$ rarely $3=$ sometimes $4=$ frequently $5=$ very frequently). The respondents were also required to indicate from experience, the extent each of the four subcontracting arrangements contribute to material wastage on site by responding to 5 point Likert scale ranging from $1=$ "very low", 2 = "low", 3 = "medium", 4 = "high", 5= "very high". The respondents were also required to rate fourteen (14) identified building materials in the order of their level of wastage during construction activities on site based on their experience using 5 point Likert 
Levels of material wastage and sub-contracting options

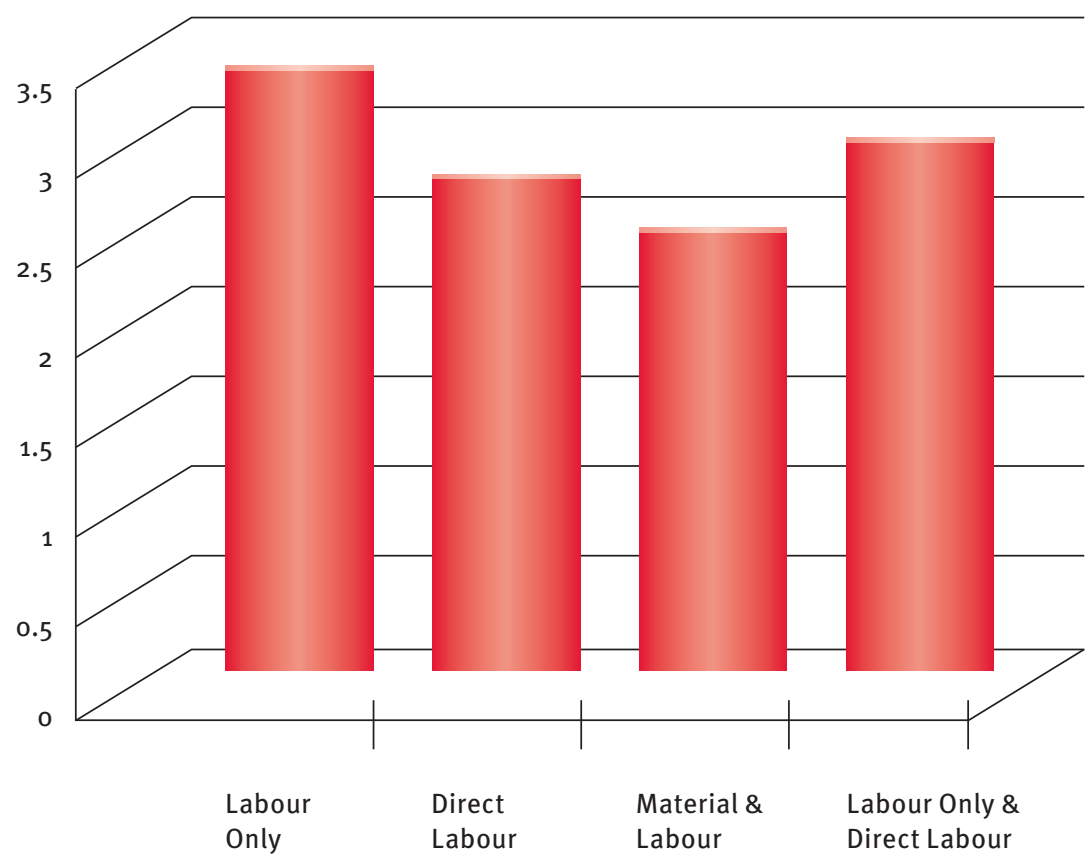

Figure 1 Levels of material wastage and sub-contracting options

scale ranging from $1=$ "very low", $2=$ "low", 3 = "medium", 4= "high", to $5=$ "very high". Furthermore, the respondents were required to indicate the percentage contribution of each of the fourteen (14) identified building materials wastage to project cost overrun based on their experience on a Likert scale of $0-5$ where $0=$ below $10 \%, 1=10-20 \%$ $2=21-30 \% 3=31-40 \% 4=41-50 \% 5$ = above $50 \%$. Finally, the respondents were required to rate sixteen (16) identified factors that contributes to material wastage on site in order of magnitude based on their experience by responding on scale 1-5 [1= "very low", $2=$ "low", 3 = "medium", 4= "high", 5= "very high",].

Questionnaire were distributed by hand to construction managers, site managers, chief estimators, site engineers, project managers and other key personnel involved in construction operations using random sampling technique. First, population was stratified based on organisational types (client, and contracting organisations), followed by simple random sampling

\section{Results and discussion}

Organizational details of respondents.

The study sought to know the details of the respondents' organization. This is presented in Table 1 . The analysis shows that $64.3 \%$ are contracting organization, $30.4 \%$ are client organization while $5.3 \%$ practice both.

Only $14.3 \%$ of the companies have below 5 years experience in construction, $17.9 \%$ have been in operation for 5-10 years, $19.6 \%$ have been in operation for $11-15$ years, $8.9 \%$ have been operation for 16-20 years while those with over 20 years experience in operation has the highest response of $39.3 \%$. This implies that the respondents organization have adequate experience in construction operation and hence information on material wastasge obtained from them will be reliable.

\section{Material wastage and}

sub-contracting arrangement

The study sought to know how each sub-contracting arrangements contributes to material wastage on sites. The result presented in Figure 1 shows that Labour only sub-contracting option (mean $=3.41$ ) have high contribution to material wastage on construction sites, this was followed by labour only $\&$ direct labour option and direct labour only with mean response of 2.96 and 2.88 respectively. The results also reveal that material and labour option with mean response of 2.55 have medium contribution to material wastage on construction sites. It's not surprising that labour only subcontracting option contribute highest to material wastage. This is because the main contractor bears cost of waste generated in this arrangement as identified in Tam et al. (2007).

Degree of building material wastage on construction sites.

The study sought to know the most wasteful material during building construction activities on sites. The respondents were required to rate the identified materials in the order of their level of wastage during building construction activities on site based on their experience by responding on a 5-point Likert scale ranging from 1- 5 [1= "very low", 2 = "low", 3 = "medium", 4= "high", 5= "very high"]. The result of the analysis is presented in Table 2. The result reveals that out of 14 most frequently used building materials investigated, mortar from plastering/rendering top the list of most wasteful material with mean score of 3.32. This was followed by timber formworks, with mean score of 3.23 , sandcrete blocks, with mean score of 3.16 , concrete with mean score of 2.79 and ceramic/vitrified tiles with mean score of 2.70 in that order. The results also reveal building materials that have low wastage level during construction activities on sites. These are Steel formwork with mean score of 1.5 , Long span aluminum roofing sheet with mean score of 1.88 , Iron bar with mean score of 2.14 , Paints with mean score of 2.16 and fibre cement roofing sheet 


\begin{tabular}{|c|c|c|c|}
\hline Building materials & $\mathbf{N}$ & $\begin{array}{l}\text { Mean } \\
\text { response }\end{array}$ & Rank \\
\hline Mortar from plastering / rendering & 56 & $3 \cdot 32$ & 1 \\
\hline Timber formworks & 56 & 3.23 & 2 \\
\hline Sandcrete blocks & 56 & 3.16 & 3 \\
\hline Concrete & 56 & 2.79 & 4 \\
\hline Ceramic/Vitrified tiles & 56 & 2.70 & 5 \\
\hline Clay tiles & 56 & 2.66 & 6 \\
\hline Wood used for flooring & 56 & 2.52 & 7 \\
\hline PVC tiles & 56 & 2.36 & 8 \\
\hline Bricks & 56 & 2.27 & 9 \\
\hline Fibre- cement roofing sheets & 56 & 2.21 & 10 \\
\hline Paints & 56 & 2.16 & 11 \\
\hline Iron bars & 56 & 2.14 & 12 \\
\hline Long span aluminum roofing sheets & 56 & 1.88 & 13 \\
\hline Steel formworks & 56 & 1.50 & 14 \\
\hline
\end{tabular}

Table 2 Rank order of material wastage on construction site

with mean score of $\mathbf{2 . 2 1}$. The finding reported in this study tends to support the outcome of earlier studies that the most wasteful building material on construction sites is mortar from plastering/rendering (Formoso et al. 2002). Formoso et al's (2002) study attributed the high wastage level in mortar from plastering/ rendering to lack of modular coordination in the structural elements and deviation from the actual design. This implied that more mortar will be used on such elements such as beams and column that have deviated from the initial design. Excessive mortar could also be used in block work joints if the blocks are not uniform in their sizes. Chu (2004) in a similar study in Hong Kong identified the percentage contribution of various construction materials to waste on site. These include mortar from plastering/ screeding $15 \%$, concrete $4 \%$, block work $10 \%$, and packaging $5 \%$. Formoso et al (2002) observed that wastage in concrete could also occur as a result of failure in formwork and means of transportation. Non adherence to mix design can also contribute to wastage in concrete. Tam et al (2007) noted that the cause of wastage in timber formwork is due to natural deterioration and waste from cutting. The wastage level in timber formwork can be as high as $20 \%$ in foundation works. The high wastage level of timber formwork in foundation could be due to the wet nature of most foundation works, which encourage the deterioration of timber It is worthy of note that both dry and wet weather has effect on timber formwork. The result also revealed that the building materials with low level of wastage are made from Steel. This could be due to their durability and the ease of re-use over time. This point is buttressed by a study in Egypt by Gihan, Ahmed, Adel (2010) which reveal that steel reinforcement has low percentage of wastage of about $5 \%$ compare to $\mathbf{2 0} \%$ for sand in their study.

Percentage contributions of material wastage to cost overrun

The study sought to know the percentage contributions of wasted building material to project cost overrun. The respondents were required to indicate the percentage contribution of each of the identified building materials wastage to project cost overrun based on their experience by responding on Likert scale ranging from scale $0-5[0=$ below $10 \%, 1=10-20 \% 2=21-30 \% 3=$ $31-40 \% 4=41-50 \% 5=$ above $50 \%]$. The weighted mean average is used in the interpolation of the percentage for each of the building material. (i.e. building material with mean response average $=0.5$ will be on scale 1 , while those with mean response average $=1.5$ will be on scale 2 , in that order). The result of the analysis is presented in Tables 3. The result in Table 3 shows the mean and percentage contribution of each building material to project cost overrun. The results reveal four building materials that have between $31-40 \%$ contributions to project cost overrun from it wastage during construction activities on sites. These are concrete with mean score of 3.0 , which ranked first. This was followed by mortar from plastering/rendering with mean score of 2.6, sandcrete block with mean of 2.5, and timber formwork with mean score of $\mathbf{2 . 5}$, in that order. The results also reveal other categories of building materials that has percentage contribution of between $21-30 \%$ to project cost overrun. Majority of the building material are in these categories. These are Iron bars with mean score of $\mathbf{2 . 4}$, Ceramic/ vitrified tiles with mean score of 2.3, Clay tiles, Fibre cement roofing sheets, wood used for Flooring and Bricks with mean score of 2.1apiece, PVC tiles with mean score of 2.0, Paints 
with mean score of 1.9 Long span aluminum roofing sheets with mean score of 1.9 and Steel formwork with mean score of 1.7, which ranked least. Table 3 shows the percentage contribution of various building material wastage on construction site to project cost overrun. A recent study in Nigeria by Ameh, Soyingbe and Odusami (2010) identified waste on sites as one of the factors that contribute to project cost overrun. From Table 3 the four (4) top ranked building material that has high percentage contribution to project cost overrun are concrete (mean = 3.0), Mortar from plastering (mean =2.6), sandcrete block (mean $=2.5$ ) and timber formwork (mean $=2.5$ ) in their order of importance. The percentage contribution from these building materials wastage to project cost overrun is between $31-40 \%$. From literature it has been observed that waste from plastering is ranked highest. Two independent studies by Pinto and Agopyan (1994) and Soibelman (1994) in Brazil, identified highest wastage level of $46 \%$ and $48 \%$ for mortar, and $12 \% \& 2 \%$ for concrete respectively. Although mortar has been identified as the most wasteful material on construction sites, it does not have the highest percentage contribution to project cost overrun but concrete does as it is showed in their mean average. This could be so since the cost of producing (1m3) of concrete could produce (10 m3) of mortar. This implied that wastage from concrete contribute more to project cost overrun even at very low wastage rate.

The percentage contribution of majority of the building materials wastage to cost overrun is between $21-30 \%$ and none of the identified building materials has a percentage contribution below $20 \%$. This is a clear evidence that wastage and it resultant effects of additional cost on project is present in every building material, although the extent may varies from one building material to another. According to Teo et al.(2009) material wastage is not

\begin{tabular}{|l|c|c|c|c|}
\hline Building materials & Percentage N & Contribution & Mean & Rank \\
\hline Concrete & 56 & $31-40$ & 3.0 & 1 \\
\hline Mortar from plastering /rendering & 56 & $31-40$ & 2.6 & 2 \\
\hline Sandcrete blocks & 56 & $31-40$ & 2.5 & 3 \\
\hline Timber formwork & 56 & $31-40$ & 2.5 & 3 \\
\hline Iron bars & 56 & $21-30$ & 2.4 & 5 \\
\hline Ceramic/Vitrified tiles & 56 & $21-30$ & 2.3 & 6 \\
\hline Clay tiles & 56 & $21-30$ & 2.1 & 7 \\
\hline Fibre- cement roofing sheets & 56 & $21-30$ & 2.1 & 7 \\
\hline Wood used for flooring & 56 & $21-30$ & 2.1 & 7 \\
\hline Bricks & 56 & $21-30$ & 2.1 & 7 \\
\hline PVC & 56 & $21-30$ & 1.0 & 11 \\
\hline Paints & 56 & $21-30$ & 1.9 & 12 \\
\hline Steel formw span aluminum roofing & 56 & 1.9 & 13 \\
\hline
\end{tabular}

\section{Table 3 Percentage Contributions of material wastage to cost overrun}

always avoidable .It occurs throughout the industry irrespective of the size of the building, organization, the value and duration of the contract or variety of the building types. It is worth noting that the least and the highest percentage contribution of material wastage to cost overrun is between $21-30 \%$ and $31-40 \%$ respectively. The average percentage contribution of building material wastage to project cost overrun is between $21-30 \%$ this finding tends to support the assertion of Bossink and bornwers (1996) who observed that $20-30 \%$ of building material purchased end up as waste on site which can be viewed as their percentage contribution to project cost overrun.

\section{Factors that contributes to material} wastage on construction sites.

The study sought to know the factors that contribute to material wastage.
The result of the analysis presented in Table 4 reveal five high contributory factors to material wastage on construction sites. These are poor supervision, which ranked first with mean $=$ 3.79 , followed by re-work with mean= 3.75 , and poor material handling, design related errors, and inadequate workers' skill with mean $=3.71,3.59$ and 3.54 respectively. The remaining 10 identified factors have medium contribution to material wastage during construction activities on site. This finding is consistent with an earlier study in Nigeria (Dania et al. 2007) in which poor supervision, poor workmanship, facilities for storage and re-work were identified as having high contribution to on- site material wastage. This finding shows the need for proper training for all site personnel ranging from the site manager to various work packages headsmen on material wastage 


\begin{tabular}{|c|c|c|c|}
\hline $\begin{array}{l}\text { Material wastage } \\
\text { Contributory factors }\end{array}$ & $\mathbf{N}$ & $\begin{array}{c}\text { Mean } \\
\text { response }\end{array}$ & Rank \\
\hline Poor supervision & 56 & 3.79 & 1 \\
\hline Re-work & 56 & 3.75 & 2 \\
\hline Poor material handling & 56 & 3.71 & 3 \\
\hline Design related errors & 56 & 3.59 & 4 \\
\hline Inadequate workers' skill & 56 & 3.54 & 5 \\
\hline Inappropriate specification & 56 & 3.29 & 6 \\
\hline Buildability problems & 56 & 3.27 & 7 \\
\hline Improper packaging & 56 & 3.25 & 8 \\
\hline $\begin{array}{l}\text { Lack of management of } \\
\text { the design process }\end{array}$ & 56 & 3.14 & 9 \\
\hline Construction related error/omission & 56 & 3.12 & 10 \\
\hline Theft and vandalism & 56 & 3.11 & 11 \\
\hline $\begin{array}{l}\text { Lack of integration of waste } \\
\text { reduction- plan in the design and } \\
\text { construction proces }\end{array}$ & 56 & 3.09 & 12 \\
\hline $\begin{array}{l}\text { Negligence and care free attitude } \\
\text { of management }\end{array}$ & 56 & 3.04 & 13 \\
\hline Lack of waste management plan & 56 & 2.79 & 14 \\
\hline Absence of site waste manager & 56 & 2.68 & 15 \\
\hline
\end{tabular}

Table 4 Factors that Contributes to material Wastage on Construction site

on site. According to Enakayake and Ofori (2000) the best way to control waste is to prevent it occurrence in the first place.

\section{Test of hypotheses}

Hypothesis one was tested using chisquare test at $p \leq 0.05$. The result of the test is presented in Table 5. As shown, the chi-square values ( $x 2$ ) for labour only, direct labour, material \& labour and direct labour and labour only are 9.536, 19.179, 17.214 and 25.857 respectively while their $\mathrm{p}$-value are $0.049,0.001,0.002 \& 0.000$ respectively. These $p$-values are less than the critical $p$-value $=0.05$. Therefore the alternate hypothesis is accepted. The result indicate that a significant relationship exist between labour only, direct labour, material \& labour and direct labour and labour only subcontracting arrangements and the level of wastes generated from building materials during construction on sites.

This result is consistent with an earlier study in Hong Kong by Tam et al (2007) which shows that waste generated on construction sites has a direct link with subcontracting arrangements. Labour only subcontracting arrangements tends to generate more waste on site since labour only subcontractors do not pay for the wastage but main contractor does (Tam et al, 2007). It's worth noting that no matter the type of subcontracting arrangement chosen material wastage will still occur.
According to Skoyles and Skoyles as cited by Tam et al (2007) different subcontracting arrangements could cause different extents of material wastage.

Hypothesis two was tested at $p$-value $\leq 0.01$. The result as presented in Table 6, indicates that the rho value $=477^{\star * *}$ and $p$-value $=(0.000)$. This $p$-value is less than the critical $p$-value (o.01) .Therefore the alternate hypothesis is accepted. It implied that the higher the level of material wastage the higher the project cost overrun. According to Hammassaki and Neto (1994) and Pinto and Agopayan (1994), $20-30 \%$ of construction material are wasted during construction operation. The equivalent of these materials must be purchased to make up for the waste which amount to additional cost to the project. Akinkurolere and Franklin (2005) stated that material wastage brings extra cost to the construction project as well a reduction in contractor's profit. In this study, mortar, timber formwork, sandcrete block and concrete ranked as the most wasteful material during construction operation on site whilst concrete, mortar sandcrete block and timber formwork ranked as the most contributory factor to cost overrun.

\section{Summary of study}

Consensus is that the cost of building material alone constitute over $50 \%$ of construction project cost in Nigeria. In Nigeria, the construction industry accounts for $70 \%$ of the gross domestic product. It is generally believed that building material wastage during construction operations contributes to project cost overrun. This means that any improvement in building material wastage level on construction sites has the potential to enhance the construction industry's performance with cost-saving benefits. To achieve the objective of the study, the following research questions were formulated: 


\begin{tabular}{|l|c|c|c|c|}
\hline Variables compared & X2-value & df & p-value & Decision \\
\hline $\begin{array}{l}\text { Labour only \& level of waste } \\
\text { generated }\end{array}$ & 9.536 & 4 & 0.049 & Accept H1 \\
\hline $\begin{array}{l}\text { Direct labour only and level } \\
\text { of waste generated }\end{array}$ & 19.214 & 4 & 0.002 & Accept H1 \\
\hline $\begin{array}{l}\text { Material \& labour and level } \\
\text { of waste generated }\end{array}$ & 17.214 & 4 & 0.001 & Accept H1 \\
\hline $\begin{array}{l}\text { Labour only \& direct labour } \\
\text { and level of waste generated }\end{array}$ & 25.857 & 3 & 0.000 & Accept H1 \\
\hline
\end{tabular}

Table 5 Chi-square test $\left(X^{2}\right)$ of independence computed for the relationship between sub-contracting arrangements and level of waste generated on site

\begin{tabular}{|l|l|c|c|}
\hline Wastage level & Pearson Correlation & Wastage & Cost overrun \\
\hline & Sig.(2-tailed) & 1 & 0.477 \\
\hline Cost overrun & Pearson correlation & 0.477 & 1 \\
\hline & Sig(2-tailed) & 0.000 & \\
\hline
\end{tabular}

** Correlation is significant at $p \leq 0.01$ level (2-tailed)

Table 6 Pearson Correlation test showing the relationship between the level of material wastage on site and project cost overrun

which of the building material constitute the most wasteful construction material on site, what is the percentage contribution of material wastage to cost overrun, What are the factors that contribute to material wastage on sites and to what extent does subcontracting options contributes to material wastage on site?

Two hypothesis were postulated for the study to test the relationship between subcontracting options, project cost overrun and the level of waste generated from building material during construction operations.

A cross-sectional survey research design was adopted for the study. Questionnaires were used as the principal instrument for collecting the primary data from the respondents. Total samples of eighty (80) respondents were drawn from register of building contractors and private developers within Lagos metropolis. Fifty six (56) questionnaires were completed and returned representing an aggregate response rate of $70 \%$. Frequency, percentages, mean score, Pearson correlation coefficient, and Chi-square were used in analysis data collected for the study.

Findings show that the most wasteful building material during construction operation is mortar from plastering/rendering. It further reveals that labour only subcontracting options have high contribution to material wastage. The study show that the average percentage contribution of building material wastage to project cost overrun is between $21-30 \%$. Poor supervision, re-work, and poor material handling in that order were identified as factors that have high contribu- tion to material wastage on sites. The study further established that significant relationship exist between subcontracting options, cost overrun and waste generated from building material during construction.

\section{CONCLUSIONS}

The findings of this study serve as the basis for making the following conclusions:

- The most wasteful building material during construction operations on site is mortar from plastering/rendering and it is due to lack of modular coordination in the structural elements and deviation from the actual design.

- Labour only subcontracting options contribute most to building material wastage during construction activities on sites as compared with other options.

- Material and labour subcontracting options has low contribution to material wastage on construction sites.

- The average percentage contribution of building material wastage to project cost overrun is between $21-30 \%$.

$\checkmark$ None of the identified building materials wastage has below $20 \%$ contribution to project cost overrun.

> There is significant relationship between the level of waste generated from various building materials on construction sites and the types of subcontracting arrangement used by the contractor.

\section{Study limitation}

This study adopts a survey research design and relies on professionals' perception of material wastage during construction operation which is considered a subjective assessment. Future study should adopt a case study research design and actual measurement of materials wastage and associated cost overruns. 


\section{References}

(ABS) Australia Bureau for Statistics, 2013. The Waste Wise Construction Programme. [online]. Available :http://www. abs.gov.au/ausstats/abs@.nsf/ Previousproducts/1301.oFeature\%20Article2 52003 ?opendocument $\&$ tabname $=$ Summary $\&$ prodno $=1301.0 \&$ issue $=2003 \&$ num $=\&$ view $=$ [Accessed: 26/05/2013]

Agyekum, K., Ayarkwa, J. and Adinyira, E.(2012). “Consultants' perspectives on materials waste reduction in Ghana”, Engineering Management Research, 1(1), pp138-150.

Akanni, P. O. (2007). "An empirical survey of the effect of materials wastage on contractors' profit level in construction projects", The professional Builders, pp35-46.

Akinkurolere, 0.0. and Franklin, S.0. (2005), "Investigation into waste Management on Construction sites in South Western Nigeria", American Journal of Applied Sciences, 2 (5),ppg80-984.

Ajayi, O.M., Koleoso, H.A., Soyingbe, A.A. and Oladiran 0. J. (2008), "The practice of waste management in construction sites in Lagos state; Nigeria”, The construction and building research conference of the Royal Institute of Charted Surveyors, Dublin Institute of Technology 4-5 September.

Amatruda, J., (2012), "Evaluating and Selecting Green Products”, Available [online] at: http://www.wbdg.org/ resources/greenproducts.php, [Accessed: 25/05/2013].

Ameh, O.J., Soyingbe, A. A and Odusami, K.T. (2010), “Significant Factors Causing Cost Overrun in Telecommunication Projects in Nigeria", Journal of Construction in Developing Countries, 15(2), pp 49-67.

Angulo, S. C., John, V. M., Kahn, H. and Ulsen, C. (2003), "Characterisation and recyclability of construction and demolition waste in Brazil”, In international conference on the environmental and technical implications with alternative materials, ISCOWA, San Sebastian.

Angulo, S. C., Ulsen, C., John, V. M., Kahn, H., and Cincotto, M. A. (2009), "Chemicalmineralogical characterization of $C \& D$ waste recycled aggregates from São Paulo, Brazil”, Waste management, 29(2), pp721-730.

Baldwin, A., Poon, C. S., Shen, L. Y., Austin, S. and Wong, I. (2009), "Designing out waste in high-rise residential buildings: Analysis of precasting methods and traditional construction", Renewable energy, 34(9), pp2067-2073.

Bossink, B.A.G. and Brouwers, H. J.H. (1996), “Construction Waste Quantification and Source Evaluation", ASCE Journal of Construction Engineering and Management, 122(1), pp55-6o.

Cheung, C.W. (1993), "Reduction of Construction Waste”, Final Report. The Hong Kong Polytechnic University, Hong Kong.

Chu, E. (2004), “Waste Minimization”, Building and environment, 39 (7), pp851-861.

CIRIA (1999), "Waste Minimization and Recycle in Construction", Boardroom Handbook.

Dania, A.A., Kehinde, J.O. and Bala, K. (2007), "A study of construction material waste management practices by construction firms in Nigeria”, Building Research Reports series, Caledonia University, Scotland UK, pp121-129

Ekanayake, L.L. and Ofori, G. (2000), “Construction Material Waste Evaluation" in Proceedings of strategies for sustainable Built Environment, Pretoria, South Africa, pp23-25.(EPD) Environmental Protection Department, (2010), “Monitoring Solid Waste in Hong Kong”, Waste Statistics for 2009. EPD, Hong Kong SARG.

Formoso, C. T., Isatto, E. L., and Hirota, E. H. (1999). "Method for waste control in the building industry", In Proceedings IGLC (Vol. 7, p. 325).

Formoso, C. T., Soibelman, L., De Cesare, C., and Isatto, E. L. (2002), “Material waste in building industry: main causes and prevention", Journal of Construction Engineering and Management, 128(4), 316325.

Gihan L.G., Ahmed R. A, and Adel, E.G (2010), "Material Waste in Egyptian Construction Industry" PhD Thesis at the Faculty of Engineering, University of Cairo, Egypt.

Hammassaki L.T. and Neto, C.S. (1994), "Technical and Economic aspect of

Construction demolition Waste Utilization", Sustainable Construction, 1st Conference of

Charted Institute of Building. Centre for Construction and Environment, Gainesville pp395-403.

Hore, A. V., Kehoe, J. G., Mumumllan, R. and Penton, M. R. (1997), “Construction Management Finance Measurement”,
Macmillan press Ltd London.

Junior, A.C., L., and Fucale, S. (2009), "Quantitative Assessment of Waste Management in Brazilian Construction Sites", Proceedings Sardinia 2009, Twelfth International Waste Management and Landfill Symposium, S. Margherita di Pula, Cagliari, Italy.

Keal L. (2007), “Reducing material wastage in construction". Available (online) at www. wrap .org.uk/construction. Accessed: 10/3/2010.

McLaren, W., (2009) US Buildings Account for $40 \%$ of Energy and Materials Use. [online]. Available at: http://www.treehugger.com/ sustainable-product-design/us-buildingsaccount-for-40-of-energy-and-materialsuse.html, Accessed: 25/05/2013

Napier, T., (2012). “Construction Waste Management", National Institute of Building Science, Available [online]. at :http://www. wbdg.org/resources/cwmgmt.php Accessed: 25/05/2013].

Perry, F., and Kirsty, M. (2007), “Assessing brick waste on domestic construction sites for future avoidance" Available [online] at: http://epress.lib.uts.edu.au/research/ handle/10453/11232?show=full [Accessed: 25/05/2013]

Pinto T. P. and Agopayan.V. (1994),

“Construction Waste as raw Materials for Lowcost Construction Products", 1st Conference of Charted Institute of Building. Centre for Construction and Environment, Gainesville pp335-342.

Rameezdeen, R. and Kulatunga, U. (2004), "Material wastage in construction sites: identification of major causes”, Journal of Built-Environment Sri Lanka, Vol. 4(2), pp35-41.

Rogoff, M. J. and William, J. F. (1994), Approaches to Implementing Solid waste Recycling Facilities, Park Ridge, N.J. Noyes.

Saraiva, T. S., Borges, M.M., and Filho, A.C., (2012), "The Importance of Recycling of Construction and Demolition Waste", PLEA2012 - 28th Conference, Opportunities, Limits \& Needs Towards an environmentally responsible architecture Lima, Perú 7-9 November 2012

Shen, L.Y., Tam, V.W.Y., Tam, C.M. and Ho, S. (2002), "Material Wastage in Construction Activities-A Hong Kong Survey", CIBW107: Creating a sustainable construction industry 
in developing countries 11- 13 November,

125-132.

Soibelman, L. (1994), “As perdas de materiais na construcao de edifica-coes: suaincidencia e seu controle. (Material waste in building construction: occurrence and control)", M.Sc dissertation Federal Univ. of Rio Grande do Sul, Porto Alegre, Brazil (in Portuguese).

Tam, V. W., Shen, L. Y., and Tam, C. M. (2007), "Assessing the levels of material wastage affected by sub-contracting relationships and projects types with their correlations", Building and Environment, 42(3), 1471-1477.

Teo, S.P., Abdelnaser, O. and Abdul, H. K. (2009), “Material wastage in Malaysian construction industry", International conference on Economic and Administration, Faculty of

Administration University of Bucharest Romania, pp257-264. (UNEP) United Nations Environment Program. (2007). Buildings and Climate Change:

Status, Challenges and Opportunities. Available [online] at: http://www.unep.org/sbci/pdfs/ BuildingsandClimateChange.pdf [Accessed: 25/05/2013]

Urio, A. F. and Brent, A. C. (2006), "Solid waste management strategy in Botswana: the reduction of construction waste", Journal of the South African Institute of Civil Engineering. Technical paper 585, 48(2), pp18-22

(WGBC) World Green Building Council, (2010), Green Building Facts and Figures. Available [online] at: http://www.ukgbc.org/system/ files/private/documents/Statistics $\% 20$ on $\% 20$ Green $\% 20$ Buildings, $\% 20$ Building $\% 20$ Sector\%20and\%2oClimate\%2oChange.pdf [Accessed: 25/03/2013]

Yu, A. T., Poon, C. S., Wong, A., Yip, R., and Jaillon, L. (2012), “Impact of Construction Waste Disposal Charging Scheme on work practices at construction sites in Hong Kong”. Waste Management. pp 138-146 